\title{
POLITENESS STRATEGIES ON "HARRY POTTER AND THE HALF BLOOD PRINCE" MOVIE
}

Bertaria Sohnata Hutauruk

FKIP Universitas HKBP Nommensen Pematangsiantar

riana.hutauruk@yahoo.com

\begin{abstract}
This research deals with the use Positive Politeness in "Harry Potter and the Half Blood Prince" Movie. To do the research, the writer formulates the problem as follow: (1) What Positive Politeness strategies are used in "Harry Potter and The Half Blood Prince" Movie? 2. What is the most dominant strategy of Positive Politeness Used in "Harry Potter and The Half Blood Prince" Movie? This study is focused on Brown and Levinson (1987) positive politeness theory by using fifteen strategies of positive politeness. The objective of the study are to describe and determine the positive politeness used in that movie. The data are obtained from all the dialogues in that movie. This study was conducted by using descriptive qualitative design. The subject of this study is "Harry Potter and the Half-Blood Prince" movie, and the objects are the fifteen strategies of positive politeness. The techniques of collecting data are by watching movie, identifying and transcribing the script of the dialogues then put them into columns. The data is analyzed by identifying and transcribing the script of the dialogues, classifying the positive politeness strategies used in that movie then counting it and find out the dominant positive politeness strategy. The findings of the data analysis show that there are thirteen of fifteen strategies of positive politeness found in the movie each with the number and percentage of occurrences. Politeness strategy is important in our life because it can make harmonious interactions.
\end{abstract}

Keywords: politeness, strategies, movie

\begin{abstract}
ABSTRAK
Penelitian ini tentang penggunaan positive politeness dalam film "Harry Potter and the Half Blood Prince." Untuk melakukan penelitian ini, penulis memformulasikan masalah penelitian sebagai berikut: (1) Apakah strategi positive politeness yang digunakan dalam film "Harry Potter and The Half Blood Prince"? (2) Apakah strategi positive politeness yang paling dominan digunakan dalam film "Harry Potter and The Half Blood Prince"? Kajian ini berfokus kepada teori Brown and Levinson (1987) yang menggunakan 15 strategi positive politeness. Tujuan dari kajian penelitian ini adalah untuk menggambarkan dan menentukan jenis positive politeness yang digunakan dalam film tersebut. Data diperoleh dari percakapan yang ada dalam film. Kajian penelitian ini menggunakan rancangan deskriptif kualitatif. Subjek penelitian adalah film "Harry Potter and the Half-Blood Prince", dan objek penelitian adalah 15 strategi positive politeness. Teknik pengambilan data dengan menonton film, mengidentifikasi dan mentranskripsikan percakapan kemudian menyajikan di dalam kolom tabel. Data dianalisis dengan mengidentifikasi dan mentranskripsikan percakapan, mengklasifikasikan strategi positive politeness menggunakan film tersebut dan menemukan strategi yang paling dominan. Penemuan dari data analisis menunjukkan bahwa ada 13 strategi positive politeness ditemukan dalam film, masing-masing dengan angka dan contoh-contoh persentasenya. Strategi positive politeness ini penting diaplikasikan dalam kehidupan kita karena itu dapat membawa keharmonisan berinteraksi.
\end{abstract}

Kata Kunci: sopan santun, strategi, film

\section{INTRODUCTION}

\section{Background of the Study}

Holmes (1992, p. 296) states that a polite person makes other feel comfortable. When people try to be polite, others are friendly towards you. In addition, it can minimize and avoid the conflict that may occur in communication or interaction. So, that is why being polite is really important. Yule $(1996$, p. 60) states that politeness in interaction can be defined as the means employed to show awareness of another person's face. It means that a polite person does not only make other feel comfortable but also they must show the awareness of face. In this sense, politeness can be accomplished in situations of social distance or closeness. Showing awareness for another person's face when that other seems socially distant is often described in terms of respect or deference. In implicating this politeness, every person has 
their strategy to be being polite. It's called politeness strategies. According to Brown and Levinson, politeness strategies are developed in order to save the hearers' "face." Face refers to the respect that an individual has for him or herself, and maintaining that "selfesteem" in public or in private situations. Usually we try to avoid embarrassing the other person, or making them feel uncomfortable. Face Threatening Acts (FTA's) are acts that infringe on the hearers' need to maintain his/her self esteem, and be respected. Politeness strategies are developed for the main purpose of dealing with these FTA's.

According to Wardaugh (1998, p. 275), he states that positive politeness leads to move to achieve solidarity through offers of friendship, the use of compliments and formal language use. It means positive politeness needs to be applied to avoid conflict between the speaker and the hearer in communication. Also it usually tries to minimize the distance between them by expressing solid interests and respects in the hearer's need. In other words, we can show our respects to other by using positive politeness in communication. Based on explanation above, the researcher wants to know further about positive politeness strategy. Therefore, the researcher chooses a research of politeness strategies used in the movie entitled "Harry Potter and The Half Blood Prince". This is a fantasy adventure film directed by Yates and based on the novel of the same name J. K. Rowling. It is called as a fantasy adventure film because this film takes the audience to netherworld places (or another dimension) where events are unlikely to occur in real life. It transcends the bound of human possibility and physical laws. It often has an element magic, myth, wonder, and the extraordinary. This film has exciting story with new experiences or exotic locales. It is the sixth installment in the Harry Potter film series, and is written by Steve Kloves and produced by David Heyman and David Barron. This film is begun on 24 September 2007, with the film being released in cinemas worldwide on 15 July 2009.

In this study, the researcher will try to describe the strategies of positive politeness in Harry Potter and Half Blood Prince. This movie is a fantasy adventure film which takes the audience to netherworld places (or another dimension) where events are unlikely to occur in real life. It has exciting story with new experiences or exotic locales. In fact many people have a lack of understanding about the story politeness of this movie. There are miss-understanding about the story of this film. They have many kinds of perceptions, thoughts, and feelings about the story of Harry Potter's movie especially the politeness strategies of this movie. They think that the story of this film is full of magic. So, that is why the researcher chooses that movie because the researcher wants to resolve the lack of understanding about this movie. So that the reader can get a good meaning and understanding about this movie. The researcher also chooses this movie because the researcher is interested in the story especially because this movie is a fantasy and the language is easy to understand, the researcher wants to know the characters, and also because politeness strategies in movie has never been studied.

In this research, the researcher will use the fifteen strategies of positive politeness to analyze Harry Potter and The Half-Blood Prince Movie based on Brown and Levinson's theory (1987). They are notice, attend to addressee, exaggerate, intensify interest to addressee, use in group identity markers, seek agreements, avoid disagreement, presuppose/raise/assert, joke, assert or presupposes speaker's knowledge, offer, promise, be optimistic, include both speaker and addressee, give (ask for) reasons, assume or assert reciprocity, and give gifts to addressee. And at last, we will find what positive politeness strategies are used in Harry Potter and The Half-Blood Prince Movie and what the most dominantly strategy of positive politeness is used in Harry Potter and The Half-Blood Prince Movie.

\section{Research Questions}

Based on the background written above, the problems of the study are formulated by the researcher as the following:

1) What Positive Politeness strategies are used in Harry Potter and The Half Blood Prince Movie?

2) What is the most dominant strategy of Positive Politeness Used in Harry Potter and The Half Blood Prince Movie? 


\section{Objectives of the Study}

The objectives of the study are formulated as follows:

1) To describe the Positive Politeness strategies used in Harry Potter and The Half Blood Prince Movie

2) To determine the most dominant strategy of Positive Politeness is used in Harry Potter and The Half Blood Prince Movie.

\section{LITERATURE REVIEW}

\section{Politeness}

Politeness, in interaction, can be defined as the means employed to show awareness of another person's face (Yule, 1996, p. 60). Furthermore, he says that being polite means getting the linguistic expression of social distance right as far as you're getting addressee is concerned. Face refers to the respect that an individual has for him or herself to maintain self-esteem in public or in private situations. Yule defines that face means self-image of a person. It refers to emotional and social sense of self that everyone has and expects everyone else to recognize (Yule, 1996, p. 60). Holmes (1955, p. 5) defines politeness as "behavior which actively expresses positive concern for others, as well as non-imposing distancing behavior", while Brown and Levinson (1987, p. 1) maintains that politeness presupposes a potential for aggression as it seeks to disarm it and make possible communication between potentially aggressive partners. From the definitions, it will be said that politeness is one of the basic social guidelines for human interaction that showed in good manner and consideration for others.

According to Brown and Levinson, politeness strategies are developed in order to save the hearers face because certain acts are liable to damage or threaten another person's face or known as "Face Threatening Acts" (FTA). An illocutionary acts has the potential to damage hearer's face (for example, insulting people, or expressing disapproval of something) or the illocutionary acts may potentially damage the speaker's own face (for example, if the speaker has to admit having botched a job). In order to reduce the possibility of damage to hearer's face or speaker's own face, he or she may adopt certain strategies.
Brown and Levinson (1987, pp. 6871) identify for different linguistics strategies that are conventionally used to perform different degrees of face threatening act (FTA) as follows.

1) Bald on-record: These provide no effort to reduce the impact of the FTA's. It will most likely shock the hearer, embarrass them, or make them feel a bit uncomfortable. However, this type of strategy is commonly found with people who know each other very well, and are very comfortable in their environment, such as close friends and family. The bald on record may be followed by mitigating devices to soften the demand, such as "please" and "would you".

2) Off-Record: The speakers are removing themselves from any imposition whatsoever.

3) Negative Politeness: the main focus for using this strategy is to assume that the speaker may be imposing on the hearer, and intruding on their space. Therefore, these automatically assume that there might be some social distance or awkwardness in the situation.

\section{Positive Politeness}

Positive politeness is redress directed to the addressee's positive face, his/her perennial desire that his/her wants (or the action/ acquisition/ values resulting from them) should be thought of as desirable. Redress consist in partially satisfying that desire by communicating that one's own wants (or some of them) are in some respects similar to the addressee's wants. Positive politeness is usually seen in groups of friends, or where people in the given social situation know each other fairly well. It usually tries to minimize the distance between them by expressing friendliness and solid interest in the hearer's need to be respected (minimize the FTA). Brown and Levinson (1987, p. 102) divide positive politeness into fifteen strategies, which are:

1) Notice, Attend to Addressee: Notice, attend to addressee (his/her interests, wants, needs and goods) suggest that speaker should take notice of aspects of addressee's condition (noticeable changes, remarkable possessions, anything which looks as through 
addressee would want speaker notice and approve of it. Examples: You must be hungry; it's a long time since breakfast. How about some lunch? Goodness, you cut your hair! By the way, I came to borrow some books.

2) Exaggerate (Approval, Interest with addressee): The use of exaggerate can be done with exaggerate intonation, stress, and other aspects of prosodic, as well as with intensifying modifiers, as in English.

3) Intensify Interest to addressee: Another way for speaker to communicate addressee that he/she shares some of his/her wants is to intensify the interest of his/her own contribution to the conversation, 'by making a good story'.

4) Use in-Group Identity Marker: Address forms are the first way to show this strategy. It is used to convey such in group membership include generic names and terms of address like mate, buddy, Mac, pal, honey, dear, duckie, luv, babe, mom, blondie, brother, sister, cutie, sweetheart, guys, fellas and so on.

5) Seek Agreement: There are some ways to show this strategy. First is safe topic. This strategy is used to seek ways in which it is possible to agree with the addressee. Safe topics allows speaker to stress his/her agreement with addressee and therefore to satisfy the addressee's desire to be 'right'. For example, if your neighbor comes home with a new car and you think it hideously huge and pollutionproducing you might still be able to say sincerely: "isn't your new car a beautiful colour!" Seeking agreement may also be stressed by repeating is used to stress emotional agreement with the utterance (or stress interest and surprise).

6) Avoid Disagreement: Avoid disagreement is claimed that people totally avoid disagreement. It is simply observed that they are much more direct in expressing agreement rather than disagreement. Token agreement is the way to show this strategy. In this case, the speaker tries to hide the disagreement by saying "yes, but...". Token agreement means speaker may go in twisting their utterances so as to appear to agree or to hide disagreement.

7) Presuppose/ Raise / Assert Common Ground: this strategy can be done by first gossip and small talks. Here speaker talk something about unrelated topic before talking what he wants. Second is point of view operation. This strategy is used to reduce the social distance between the hearer and the speaker. And the third is Personal centre switch. Here, speaker speaks as if addressees were speaker or addressee's knowledge was equal to speaker's knowledge.

8) Joke: a basic positive politeness technique, for the putting addressee 'at easy', for example in response to a faux pas of addressee, speaker may joke or a joke may minimize an FTA of requesting.

9) Assert or Presupposes Speaker's Knowledge of and Concern for Addressee's Wants: In this strategy means willingness to fit one's own wants.

10) Offer, Promise: Offers and promises are the natural outcome of choosing this strategy; they demonstrate speaker's good intentions in satisfying addressee's positive face wants.

11) Be Optimistic: Presumptuous or 'optimistic' expressions of FTAs are one outcome of this strategy. Optimistic expressions of FTAs seem to work by minimizing the size FTA. This minimization may be literally stated with the expression like sure.

12) Include Both Speaker and Addressee in the Activity: by using an inclusive 'we' form, when speaker means 'you' or 'me', he/she can call upon the cooperative assumptions and thereby redress FTAs. Nothing that let's in English in an inclusive 'we' form, common examples: Let's have a cookie, then, Let's go on with dinner.

13) Give (Ask for) Reasons: Another aspect of including Addressee in the activity is for speaker gives reasons as why he/she wants what he wants.

14) Assume or Assert Reciprocity: The existence of cooperation between speaker and addressee may also be claimed or urged by giving evidence of reciprocal rights or obligations obtaining between speaker and addressee.

15) Give Gifts to Addressee (Goods, Sympathy, Understanding, Cooperation): this last positive politeness strategy involves Speaker deciding to redress addressee's face directly by fulfilling some Addressee's wants. 
Film

A film also called a movie or motion picture is a series of still or moving images. It is produced by recording photographic images with cameras, or by creating images using animation techniques or visual effects. The origin of the name "film" comes from the fact that photographic film (also called film stock) has historically been the primary medium for recording and displaying motion pictures. Many other terms exist for an individual motion picture, including picture, picture show, moving picture, photo-play and flick. Additional terms for the field in general include the big screen, the silver screen, the cinema and the movies.

Films are cultural artifacts created by specific cultures, which reflect those cultures, and in turn, affect them. The process of film making has developed into an art form and industry. Film is considered to be an import art form, a source of popular entertainment and a powerful method for educating or indoctrinating citizens. The visual elements of cinema give motion pictures a universal power of communication. Some films have become popular worldwide attraction by using dubbing or subtitles that translate the dialogue into the language of the viewer. Films are made up of a series of individual images called frames. When these images are shown rapidly in succession, a viewer has the illusion that motion is occurring. The viewer cannot see the flickering between frames due to an affect known as persistence of vision, whereby the eye retains a visual image for a fraction of a second after the source has been removed.

\section{Harry Potter and the Half-Blood Prince Movie}

Harry Potter and the Half-Blood Prince is a 2009 fantasy adventure film directed by David Yates and based on the novel of the same name J. K. Rowling. It is called as a fantasy adventure film because this film takes the audience to netherworld places (or another dimension) where events are unlikely to occur in real life. It transcends the bounds of human possibility and physical laws. It often has an element of magic, myth, wonder, and the extraordinary. It may appeal to both children and adults. This film has exciting story with new experiences or exotic locales. Harry Potter and the Half-Blood Prince is the sixth installment in the Harry
Potter film series, and it is written by Steve Kloves and produced by David Heyman and David Barron. The film stars Daniel Radcliffe as Harry Potter, alongside Rupert Grint and Emma Watson as Harry's best friends Ron Weasley and Hermione Granger. The supporting cast features Michael Gambon, Jim Broadbent, Alan Rickman, Tom Felton and Helena Bonham Carter. This film is begun on 24 September 2007, with the film being released in cinemas worldwide on 15 July 2009. In five days the film made $\$ 394$ million, breaking the record for biggest five day worldwide gross in history. The film was also nominated for many awards, including best cinematography at the $82^{\text {nd }}$ Academy Awards and Best Special Visual Effects and Best Production Design at the $63^{\text {rd }}$ British Academy Film Awards.

\section{Synopsis of Harry Potter and the Half- Blood Prince}

Lord Voldemort is tightening his grip on both the wizarding and Muggle Worlds, sending out Death Eaters to terrorize London, and has chosen Draco Malfoy for a mission. Snape accepts Bellatrix Lestrange's challenge to make an Unbreakable Vow with Draco's mother, Narcissa, to protect Draco and carry out the assignment if he fails. Harry accompanies Dumbledore to visit former potions professor Horace Slughorn, who has gone into hiding. Slughorn agrees to return to teach at Hogwarts and Dumbledore tells Harry that Slughorn's return to Hogwarts is crucial. Leaving Fred and George's new shop, Harry, Ron and Hermione notice Draco and Narcissa associating with Death Eaters Bellatrix Lestrange and Fenrir Greyback in Borgin and Burkes. Harry believes Voldemort has made Draco a Death Eater, but Ron and Hermione are skeptical. On the Hogwarts Express, Harry spies on Draco, Who hints to his friends that he does not plan to return to Hogwarts next year. Draco discovers Harry and petrifies him and breaks his nose, but Harry is later rescued by Luna Lovegood.

At Hogwarts, Harry and Ron are admitted to Slughorn's potions class at the last minute and borrow the needed textbooks. The previous owner of Harry's copy, the "Half-Blood Prince", has annotated the book with additional instructions that allow Harry to excel in class. After making many spectacular saves as keeper on the Gryffindor 
Quidditch team, Ron becomes a Gryffindor hero and forms a relationship with Lavender Brown, leaving Hermione heartbroken. Harry discovers Hermione sobbing in the Astronomy Tower and reveals he has feelings for Ron's sister, Ginny Weasley. Harry spends Christmas with the Weasley and becomes closer to Ginny. They almost share a kiss on Christmas Eve but Bellatrix and Fenrir, intent on capturing Harry, attack and burn the Burrow. Being outnumbered, they abandon their attack as Harry, Tonks, Lupin and the Weasley watch their home burn. Suspecting that Draco is responsible for two attempts on Dumbledore's life, one of which nearly kills Ron, Harry confronts him and severely wounds Draco with a curse (Sectumsempra) from the Half-Blood Prince's book. Harry shocked at its effects, retreats as Snape heals Draco. Fearing the book in the room of requirement and share their first kiss.

Dumbledore shows Harry memories of a young Tom Riddle and reveals Slughorn retains a memory critical to Voldemort's defeat. Harry retrieves the memory, learning that Voldemort wanted information for creating Horcruxes. The Horcrux safeguards a portion of the creator's soul, granting him immortality unless the Horcruxes are destroyed. Two of Voldemort's Horcruxes have already been destroyed: Tom Riddle's diary and his mother's ring. Touching the ring, Harry twitches unconsciously, although noticed by Dumbledore. After discovering the possible location of another Horcrux, Dumbledore requests Harry's help to retrieve it. They travel to a far away cave where Harry is forced to make Dumbledore drink a mindaltering potion that hides the Horcrux, a locket. A weakened Dumbledore defends them from a horde of Inferi and apparatus himself and Harry back to the Astronomy Tower at Hogwarts. In the meantime, Bellatrix and several other Death Easters enter the castle with Draco's help. Dumbledore first tells Harry to fetch Snape for help, but instead orders him to hide when footsteps approach. Draco reveals that he has been chosen by Voldemort to kill Dumbledore, but he is unable to follow through. Snape enters and casts the Avada Kedavra curse, killing Dumbledore and then escaping from the castle with draco and the Death Eaters. In their wake Bellatrix casts the Dark Mark, destroys the Great Hall and sets fire to Hagrid's hut. Harry tries to stop them, but snape deflects Harry's spells and Bellatrix stuns him. Snape reveals to Harry that he is the Half-Blood Prince and escapes. Harry returns to the school to find the staff and students mourning Dumbledore.

Harry later reveals to Ron and Hermione that the locket Horcrux was a fake. The locket contains a message from an "R.A.B." to Voldemort stating that he has stolen the real Horcrux with the intent of destroying it. His dying wish is that when Voldemort meets his match he will be mortal once more. Rather than return for their final year at Hogwarts, Harry, Ron and Hermione vow to seek out who R.A.B. was and to find the remaining Horcruxes as they discover their journey is almost over.

\section{RESEARCH METHOD}

\section{Research Design}

This research belongs to a qualitative design because it is intended to describe, explore and clarify about positive politeness strategies in Harry Potter and The Half Blood Prince Movie.

\section{Source of Data}

In conducting this research, the data are taken from the dialogues that contain positive politeness strategies produced by the characters in Harry Potter and The HalfBlood Prince Movie. The kinds of the data that will be analyzed are the script of the dialogue which is produced by the characters in Harry Potter and The Half-Blood Prince Movie.

\section{Subject of the Study}

The writer conducts the subject of this research is Harry Potter and the Half Blood Prince Movie.

\section{Object of the Study}

The writer conducts the object of the study in this research is the fifteen strategies of positive politeness strategy (Brown and Levinson, 1987, p. 102).

\section{Data Collection Procedures}

The data of the research are collected by doing the following steps: 
1. Watch Harry Potter and The Half-Blood Prince Movie several times to know the whole story.

2. Identify the script of the dialogues which are produced by the characters in Harry Potter and The Half-Blood Prince Movie which use positive politeness strategies.

3. Transcribe the script of the dialogues which are produced by the characters in Harry Potter and The Half-Blood Prince Movie which use positive politeness strategies.

4. Put them in a kind of forms or columns in the table.

\section{Data Analysis Procedures}

To answer the first problem, the technique for analyzing data will be done by the following steps:

1. Identify the positive politeness strategy in the script of the dialogues which are produced by the characters in the movie by underline with pen.

2. Transcribe the script of the dialogues which are produced by the characters in Harry Potter and The Half-Blood Prince Movie which use positive politeness strategies.

3. Classify positive politeness strategy used in the script of the dialogues which are produced by the characters in Harry Potter and The Half-Blood Prince Movie based on Brown and Levinson's (1987, p. 102) positive politeness strategies (Notice, Attend to Addressee, Exaggerate, Intensify Interest to Addressee, Use in Group Identity Markers, Seek Agreement, Avoid

Disagreement, Presuppose/Raise/Assert, Joke, Assert or Presupposes Speaker's Knowledge, Offer, Promise, Be Optimistic, Include Both Speaker and Addressee, Give (Ask for) Reasons, Assume or Assert Reciprocity, and Give Gifts to Addressee) into columns in the table.

4. To answer the second problem, the technique for analyzing data will be done by the following steps:

5. Classify positive politeness strategy used in the script of the dialogues which are produced by the characters in Harry Potter and The Half-Blood Prince Movie based on Brown and Levinson's (1987, p. 102) positive politeness strategies into columns in the table.
6. Count the positive politeness strategies used in the script of the dialogues which are produced by the characters in Harry Potter and The Half-Blood Prince Movie.

7. Find out the strategies of positive politeness that is dominantly used in Harry Potter and the Half-Blood Prince Movie.

To count the percentage of the data, the writer uses the following formula from Bungin (2001, p. 189):

$$
\mathrm{N}=\frac{f}{n} \times 100 \%
$$

$\mathrm{N}$ : The percentage of the dominant positive politeness strategy

$f \quad$ : Frequency of each positive politeness strategy.

$n$ : The total number of positive politeness strategy.

\section{Validity}

In this research, the instrument which is used for collecting data is the writer herself by using paper, pen, and laptop. The characters of Harry potter and The Half Blood Prince Movie produce politeness strategy. The characters produce some types of positive politeness strategy. So the writer wants to investigate the types of positive politeness strategy and the dominant types that are produced by the characters of Harry Potter and The Half Blood Prince Movie.

\section{FINDINGS AND DISCUSSION}

\section{Research Findings}

After analyzing the data, the writer gets some findings, they are:

1. 200 utterances of positive politeness strategies which were collected from all characters in Harry Potter and the Half Blood Prince Movie. The use of positive politeness strategies was to satisfy the hearer's desire to be found as agreeable or congenial and to be appreciated.

2. There were thirteen strategies of fifteen positive politeness found in Harry Potter and the Half Blood Prince Movie. They were: Notice/Attend to Addressee, Exaggerate Intensify Interest to Addressee, $\quad$ presuppose/Raise/Assert 
Common Ground, Assume or Assert Reciprocity And Give Gifts to Addressee (Goods, Sympathy, Understanding, and Cooperation).

3. There was no utterance that used Joke (Strategy 8) and Be Optimistic (Strategy 11) in Harry Potter and The Half Blood Prince Movie. Each positive politeness has different frequency. Notice/Attend to Addressee 5 utterances (2,5\%), Exaggerate 10 utterances (5\%), Intensify Interest to Addressee 5 utterances (2,5\%), Use in Group Identity Markers 89 utterances $(44,5 \%)$, Seek Agreement 21 utterances (10,5\%), Avoid Disagreement 4 utterances (2\%), Presuppose / Raise / Assert Common Ground 6 utterances $(3 \%)$, Joke 0 utterance $(0 \%)$, Assert or Presupposes Speaker's Knowledge of and Concern for Addressee's Wants 2 utterances (1\%), Offer and Promise 30 utterances $(15 \%)$, Be Optimistic 0 utterance $(0 \%)$ Include Both Speaker and Addressee in The Activity 5 utterances (2,5\%), Give (Ask for) Reasons 7 utterances $(3,5 \%)$, Assume or Assert Reciprocity 1 utterance $(0,5 \%)$, And Give Gifts to Addressee (Goods, Sympathy, Understanding, and Cooperation) 15 utterances $(7,5 \%)$.

The most dominant positive politeness strategies that used in Harry Potter and The Half Blood Prince Movie was the use of group identity markers. The accumulate of positive politeness strategies used in Harry Potter and The Half-Blood Prince Movie

\section{Discussion}

After finding the research further the writer goes to the discussion of research findings. It is talked about the data would be being interpreted and discussed after analyzing the positive politeness strategies from Harry Potter and The Half Blood Prince Movie. There are 200 utterances of positive politeness strategies which are collected from all characters in Harry Potter and the HalfBlood Prince Movie. The use of positive politeness strategies was to satisfy the hearer's desire to be found as agreeable or congenial and to be appreciated. Based on analyzing the script dialogues of that movie (data), the writer find thirteen kinds of positive politeness strategies namely Notice /
Attend to Addressee, Exaggerate, Intensify Interest to Addressee, Use in Group Identity Markers, Seek Agreement, Avoid Disagreement, Presuppose/Raise/Assert Common Ground, Assert or Presupposes Speaker's Knowledge of and Concern for Addressee's Wants, Offer and Promise, Include Both Speaker and Addressee in The Activity, Give (Ask for) Reasons, Assume or Assert Reciprocity, and Give Gifts to Addressee (Goods, Sympathy, Understanding, and Cooperation). Based on the finding and analyzing, the writer will discuss and interpret the data one by one.

\section{CONCLUSION AND SUGGESTION}

Based on the previous chapter, the conclusion can be formulated as the follows: From the fifteen types of positive politeness, there were thirteen strategies of positive politeness found in Harry Potter and The Half-Blood Prince Movie. They are Notice/Attend to Addressee 5 utterances $(2,5 \%)$, Exaggerate 10 utterances $(5 \%)$, Intensify Interest to Addressee 5 utterances $(2,5 \%)$, Use in Group Identity Marker 89 utterances (44,5\%), Seek Agreement 21 utterances (10,5\%), Avoid Disagreement 4 utterances (2\%), Presuppose/Raise/Assert Common Ground 6 utterances (3\%), Joke 0 utterance $(0 \%)$, Assert or Presupposes Speaker's Knowledge of and Concern for Addressee's Wants 2 utterances (1\%), Offer and Promise 30 utterances (15\%), Include Both Speaker and Addressee in The Activity 5 utterances $(2,5 \%)$, Give (Ask for) Reasons 7 utterances $(3,5 \%)$, Assume or Assert Reciprocity 1 utterance $(0,5 \%)$, and Give Gifts to Addressee (Goods, Sympathy, Understanding, Cooperation) 15 utterances $(7,5 \%)$.

There was no utterance in Harry Potter and The Half-Blood Prince Movie that belongs to Joke (Strategy 8) and $\mathrm{Be}$ Optimistic (Strategy 11).

The use in Group Identity Markers (Strategy 4) appears as the dominant strategy which is used in Harry Potter and The Half-Blood Prince Movie. 


\section{REFERENCES}

Brown, P., \& Levinson, C.L. (1987). "Politeness": Some universals in language usage. Cambridge, MA: Cambridge University Press

Bungin, B. (2003). Analisis data penelitian kualitatif. Jakarta: PT. Raja Grafindo Persada

Downes, W. (1998). Language and society. Cambridge, CA: Cambridge University Press

Film. (n.d.). Retrieved from http://en.wikipedia.org/wiki/Film.

Film Genre. (n.d.). Retrieved from http://en.wikipedia.org/wiki/Film_genr e.

Fasold, R. (1996). The sociolinguistics of language: Introduction to sociolinguistics (2nd ed.). Massachusetts, MA: Blackwell

Harry Potter and The Half Blood Prince (n.d.). Retrieved from http://harrypotter-and-the-half-blood-princescipt.html.

Harry Potter and The Half Blood Prince (n.d.). Retrieved from http://en.wikipedia.org/wiki/Harry Potter and The Half-Blood Prince.

Holmes, J. (1992). An introduction to sociolinguistics. New York, NY: Longman

http://www.filmsite.org/subgenres.html. Retrieved May 6, 2013.

Lado, R. (1964). Language: A scientific approach. New York, NY: McGrawHill,Inc.

Marjohan, A. (1988). An introduction to sociolinguistics. Jakarta: Departemen Pendidikan dan Kebudayaan

Nazir, M. (1998). Metode penelitian. Jakarta: Ghali Indonesia

Pardede, H. (2006). An introduction to sociolinguistics. Pematangsiantar: FKIP HKBP Nommensen University Pematangsiantar

Politeness. (n.d.). Retrieved from http://en.wikipedia.org/wiki/newencycl opedic.

Politeness Strategies. (n.d.). Retrieved from $\mathrm{http} / / /$ linguistics.uoregon. edu/explore/socioling/strat.html.

Romaine, S. (1994). Language in society. New York, NY: Oxford University Press
Sapir, E. (1921). Language. New York, NY: Harcourt Brace Javanovich, Inc.

Spolsky, B. (1998). Sociolinguistics. Oxford, OX: Oxford University Press.

Trudgill, P. (1974). Sociolinguistics: An introduction. Oxford, OX: Blackwell.

Wardaugh, R. (1998). An introduction to sociolinguistics. Oxford, OX: Blackwell.

Yule, G. (1996). Pragmatics. New York, NY: Oxford University Press. 